\title{
EFEKTIVITAS DAUN SIRSAK TERHADAP PENURUNAN TEKANAN DARAH PADA PENDERITA HIPERTENSI DI WILAYAH KERJA PUSKESMAS BALIBO KABUPATEN BULUKUMBA
}

\author{
${ }^{1}$ Safruddin \\ ${ }^{2}$ Nadia Alfira \\ ${ }^{1}$ Departemen Keperawatan Manajemen Stikes Panrita Husada Bulukumba \\ ${ }^{2}$ Departemen Keperawatan Medikal Bedah Stikes Panrita Husada Bulukumba
}

\section{Alamat Koresponden:}

Ns.Safruddin,S.Kep,M.Kep

Program Studi Ilmu Keperawatan

Sekolah Tinggi Ilmu Kesehatan Panrita Husada

Bulukumba, 04132514721

Hp. 085342577075

Email: Safaryahya1@gmail.com 


\begin{abstract}
ABSTRAK
Hipertensi atau tekanan darah tinggi adalah suatu peningkatan abdormal tekanan darah dalam pembuluh darah arteri secara terus menerus lebih dari suatu periode. Penderita hipertensi selain berisiko tinggi menderita penyakit jantung, juga berisiko menderita penyakit lain seperti penyakit saraf dan ginjal. Pengobatan hipertensi dapat dilakukan dengan cara farmakologis dan nonfarmakologis. Akhir-akhir ini pengobatan yang sering dilakukan oleh masyarakat ialah mengonsumsi tanaman herbal. Kemampuan tanaman herbal untuk mengontrol hipertensi sudah dibuktikan oleh nenek moyang kita selama ratusan tahun. Salah satu tanaman herbal yang terbukti mampu menurunkan tekanan darah adalah daun sirsak. Untuk menilai efektivitas daun sirsak terhadap penurunan tekanan darah pada penderita hipertensi di Wilayah Kerja Puskesmas Balibo Kecamatan Kindang Kabupaten Bulukumba. Metode penelitian kuantitatif dengan menggunakan pre experimental design yaitu rancangan penelitian eksperimental yang terdiri dari one group pretest - postest design. Populasi dalam penelitian ini adalah semua penderita hipertensi yang ada di wilayah kerja Puskesmas Balibo Kecamatan Kindang Kabupten Bulukumba sebanyak 567 orang, sampel yang diambil sebanyak 15 orang dengan teknik pengambilan sampel consecutive sampling. Instrumen yang digunakan adalah sphygmomanometer, hasilnya ditulis dalam lembar observasi. Hasil Penelitian yang didapatkan yaitu, Ada efektivitas daun sirsak terhadap penurunan tekanan darah pada penderita hipertensi di wilayah kerja Puskemsas Balibo Kecamatan Kindang Kabupaten Bulukumba. Hal ini ditunjukkan dengan hasil uji wilcoxon tekanan darah sistol didapatkan nilai $p<\alpha$ $(p=<0.001)$, dan tekanan darah diastol didapatkan nilai $p<\alpha \quad(p=0.002)$. Kesimpulan: Ada pengaruh daun sirsak terhadap penurunan tekanan darah pada penderita hipertensi di wilayah kerja Puskemsas Balibo Kecamatan Kindang Kabupaten Bulukumba. Saran: Diharapkan bagi penderita hipertensi dan tenaga kesehatan untuk memanfaatkan daun sirsak sebagai pengobatan penyakit hipertensi.
\end{abstract}

\title{
Kata Kunci: Daun Sirsak, Hipertensi, Penurunan Tekanan Darah.
}

\begin{abstract}
Hypertension or high blood pressure is an increase in normal blood pressure in blood vessels. Hypertension sufferers in addition to high risk of suffering from heart disease, are also at risk of suffering from other diseases such as nerve and kidney disease. Treatment of hypertension can be done by pharmacological and nonpharmacological methods. Lately the treatment is often done by people who consume herbal plants. The ability of herbs to control hypertension has been proven by our ancestors during various years. One of the herbal plants proven to be able to reduce blood pressure is soursop leaves. Research Objectives is To measure the level of risk of soursop to decrease blood pressure in patients with hypertension in the Work Area of Balibo Health Center, Kindang District, Bulukumba Regency. Research Methods is Quantitative research methods using pre-experimental designs, namely experimental research designs consisting of one group pretest - posttest design. The population in this study were all hypertensive sufferers who were in the work area of Balibo Community Health Center, Kindang District, Bulukumba District, as many as 567 people, 15 samples were taken with successive sampling techniques. The instrument used was a sphygmomanometer, produced in the observation sheet. Research Results is There is a problem with soursop leaves in reducing blood pressure in hypertensive patients in the Puskemsas Balibo work area, Kindang District, Bulukumba Regency. This was discussed with the results of the Wilcoxon systole blood pressure obtained $p<\alpha(p=<0.001)$, and diastolic blood pressure obtained $p$ value $<\alpha(p=0.002)$. Conclusion: There is an effect of soursop leaves on blood pressure reduction in hypertensive patients in the work area of Puskemsas Balibo, Kindang District, Bulukumba Regency. Suggestion is expected that hypertension sufferers and health workers to use soursop leaves as a treatment for hypertension.
\end{abstract}

Keywords: Soursop Leaves, Hypertension, Decreased Blood Pressure. 


\section{PENDAHULUAN}

Kesehatan menurut UU No. 23

Tahun 1992, kesehatan adalah keadaan `sejahtera dari badan, jiwa, dan sosial yang memungkinkan setiap orang hidup produktif secara sosial dan ekonomis (Achmadi, 2013).

Salah satu gangguan kesehatan yang sering terjadi adalah gangguan pada sistem kardiovaskular yaitu hipertensi. Hipertensi sering disebut silent killer atau pembunuh diam-diam karena biasanya terjadi tanpa gejala. Mengatasi hipertensi dengan tanaman herbal merupakan cara kembali ke alam (Junaedi, 2013).

Menurut World Health Organization (WHO) hipertensi adalah suatu kondisi dimana pembuluh darah memiliki tekanan darah tinggi (tekanan darah sistolik $>140$ $m m H g$ atau tekanan darah diastolik $>90$ $m m H g$ ) yang menetap. Tekanan darah adalah kekuatan untuk melawan tekanan dinding arteri ketika darah tersebut dipompa oleh jantung ke seluruh tubuh , semakin tinggi tekanan darah maka semakin keras jantung bekerja (Silpawati, 2013).

Pengobatan hipertensi dapat dilakukan dengan cara farmakologis dan nonfarmakologis. Pengobatan secara nonfarmakologis adalah dengan berolahraga dan menjaga pola makan seperti diet rendah garam. Akhir- akhir ini pengobatan yang sering dilakukan oleh masyarakat ialah mengonsumsi tanaman herbal yang diyakini mampu menurunkan tekanan darah. Daun sirsak akhir-akhir ini sering digunakan sebagai pengobatan alternatif hipertensi. Kandungan daun sirsak yang diperkirakan dapat menurunkan tekanan darah adalah kalium. Ion kalium dalam cairan ekstrasel akan menyebabkan jantung relaksasi dan juga membuat frekuensi denyut jantung menjadi lambat. Selain itu kalium juga bisa mengatur keseimbangan cairan tubuh bersama natrium, menghambat pengeluaran renin, berperan dalam vasodilatasi arteriole, dan mengurangi respon vasokonstriksi endogen, sehingga tekanan darah menurun (Joe, 2012).

Menurut data statistik World Health Organizatoin (WHO) menyatakan bahwa terdapat 24,7\% penduduk Asia Tenggara dan $23,3 \%$ penduduk Indonesia berusia 18 tahun ke atas yang mengalami hipertensi pada tahun 2014. WHO mengatakan jumlah penderita hipertensi paling banyak terdapat di Afrika, dimana hampir sebagian orang dewasa mengalami hipertensi, dan angka terendah hipertensi terdapat di benua Amerika (Rahmawati, 2014).

Menurut hasil Riskesdas tahun 2013 prevalensi hipertensi di Sulawesi Selatan yang didapat melalui pengukuran pada umur $\geq 18$ tahun sebesar $28,1 \%$ tertinggi 
di Enrekang yaitu sebesar $31,1 \%$, diikuti Bulukumba yaitu 30,8\%, Sijai 30,4\%, dan Gowa 29,2\% (Dinas Kesehatan Sulawesi Selatan, 2014).

Berdasarkan data yang diperoleh di Puskesmas Balibo Kecamatan Kindang Kabupaten Bulukumba pada tahun 2014 terdapat 476 pasien penderita hipertensi, pada tahun 2015 meningkat menjadi 1224 pasien, dan pada tahun 2016 sebanyak 567 pasien. Data yang ditemukan peneliti di Pustu Desa Somba Palioi salah satu Desa bagian dari Wilayah Kerja Puskesmas Balibo sebanyak 32 orang warga yang mengalami penyakit hipertensi dan 4 orang pernah mengalami stroke dengan riwayat hipertensi. Hasil pengamatan peneliti beberapa penderita hipertensi di Desa Somba Palioi pernah mengonsumsi daun sirsak.

Hasil penelitian Hubert Hansel (2015) judul penelitian "Pengaruh Teh Daun Sirsak Terhadap Penurunan Tekanan Darah Normal Pada Laki-Laki Dewasa Muda." Tujuan penelitian ini untuk mengetahui pengaruh teh daun sirsak terhadap penurunan tekanan darah normal pada laki-laki dewasa muda. Menggunakan metode prospektif eksperimantal laboratorium quasi. Dengan desain penelitian pre-test dan post-test, dengan menggunakan uji " $t$ " berpasangan dan uji " $\mathrm{t}$ " tidak berpasangan. Hasil uji "T" berpasangan $(p=0,000)$ menunjukkan penurunan tekanan darah yang sangat bermakna, sedangkan untuk uji "T" tidak berpasangan menunjukkan terdapat perbedaan presentase penurunan yang tidak bermakna nilai $(\mathrm{p}=0,417>0,05)$.

Berdasarkan uraian di atas peneliti tertarik untuk melakukan penelitian tentang "Efektivitas Daun Sirsak Terhadap Penurunan Tekanan Darah pada Penderita Hipertensi di Wilayah Kerja Puskesmas Balibo Kabupaten Bulukumba.”

\section{METODE}

Desain penelitian yang digunakan dalam penelitian ini adalah Pre Eksperimental Design dengan pendekatan One-Group Pretest-Posttest Design yaitu jenis penelitian yang terdapat pretest sebelum diberikan perlakuan.

Populasi dalam penelitian ini adalah warga yang menderita penyakit hipertensi yang ada di Wilayah Kerja Puskesmas Bulukumba yaitu sebanyak 567 orang.

Sampel pada penelitian ini adalah penderita hipertensi di Wilayah Kerja Puskesmas Balibo Kecamatan Kindang Kabupaten Bulukumba sebanyak 15 orang.

Teknik pengambilan sampel dalam penelitian ini adalah consecutive sampling yaitu teknik penentuan sampel dengan menetapkan subjek yang memenuhi kriteria penelitian dimasukkan dalam penelitian sampai kurun waktu tertentu, 
sehingga sampel yang diperlukan terpenuhi (Setiadi, 2013).

Instrumen penelitian untuk variabel tekanan darah adalah instrumen fisiologis menggunakan sphygmomanometer dan hasilnya ditulis dalam lembar observasi.

Peneliti mengukur terlebih dahulu tekanan darah responden sebelum pemberian air rebusan daun sirsak. Setelah responden minum rebusan daun sirsak sebanyak 7-10 lembar dalam 2 gelas air hingga airnya tersisa menjadi 1 gelas, 30 menit kemudian, peneliti mengukur kembali tekanan darah responden.

Dilakukan terhadap tiap variabel dari hasil penelitian. Analisa ini menjelaskan angka atau nilai jumlah variabel dengan ukuran presentase (Sugiyono, 2012).

Analisa data yang digunakan untuk menguji hipotesis yang telah ditetapkan yaitu mempelajari hubungan antar variabel (Sugiyono, 2012).

Untuk melihat hubungan varibel independen dengan dependen dalam penelitian ini uji statistik yang digunakan adalah uji $\mathrm{T}$ berpasangan alternatif wilcoxon.

\section{HASIL}

Berdasarkan tabel 1 Diketahui bahwa dari 15 jumlah responden, yang berjenis kelamin laki-laki sebanyak 4 orang dengan persentase $26,7 \%$ dan 11 orang yang berjenis kelamin perempuan dengan persentase $73,3 \%$. Sedangkan karakteristik responden berdasarkan umur, dari 15 reponden yang termasuk kategori dewasa sebanyak 2 orang dengan persentase $13,3 \%$, dan yang termasuk dalam kategori umur lansia sebanyak 13 orang dengan persentase $86,7 \%$.

Berdasarkan tabel 2 Diketahui bahwa dari 15 jumlah responden, yang berjenis kelamin laki-laki sebanyak 4 orang dengan persentase $26,7 \%$ dan 11 orang yang berjenis kelamin perempuan dengan persentase $73,3 \%$. Sedangkan karakteristik responden berdasarkan umur, dari 15 reponden yang termasuk kategori dewasa sebanyak 2 orang dengan persentase $13,3 \%$, dan yang termasuk dalam kategori umur lansia sebanyak 13 orang dengan persentase $86,7 \%$.

Berdasarkan tabel 3 Distribusi jumlah responden berdasarkan tekanan darah diastol pre-test dapat diketahui bahwa dari 15 responden, dilihat dari nilai median sebesar 90, nilai minimum sebesar 80, dan nilai maximum sebesar 100 .

Berdasarkan tabel 4 Distribusi jumlah responden berdasarkan tekanan darah sistol post-test dapat diketahui bahwa dari 15 responden, dilihat dari nilai mean yaitu sebesar 146, dan nilai standar deviasi sebesar 19,567.

Tabe 5 Distribusi jumlah responden berdasarkan tekanan darah diastol post-test dapat diketahui bahwa dari 15 responden, 
dilihat dari nilai median yaitu sebesar 80 nilai minimum sebesar 80 dan nilai maximum sebesar 100 .

Berdasarkan tabel 6 Dari hasil normalitas tekanan darah sistol pre-test didapatkan nilai Tests of Normality shapiro-wilk yaitu 0,099 atau >0,05, dan tekanan darah sistol post-tes di dapatkan nilai 0,065.Tests of Normality shapiro-wilk untuk tekanan darah diastolpre-test didapatkan nilai 0,001 atau $<0,05$ dan nilai tekanan darah diastol post-test adalah 0,000. Sehingga syarat untuk uji $T$ berpasangan Tidak terpenuhi, karena data tekanan darah diastol tidak normal. Oleh karena itu digunakan uji alternative Wilcoxon.

Dari hasil uji Wilcoxon tekanan darah sistol didapatkan nilai $p<\alpha \quad(p=<0.001)$, dan tekanan darah diastol didapatkan nilai $(p=0.002)$, maka dapat disimpulkan bahwa, "ada efektivitas daun sirsak terhadap penurunan tekanan darah di wilayah kerja Puskesmas Balibo Kecamatan Kindang Kabupaten Bulukumba.

\section{PEMBAHASAN}

Berdasarkan hasil penelitian dapat diketahui karakteristik responden meliputi usia, jenis kelamin, tekanan darah sebelum dan sesudah pemberian daun sirsak. Berdasarkan karakteristik jenis kelamin responden, rata- rata responden berjenis kelamin perempuan, yaitu sebanyak 11 orang atau sebesar 73,3\%, sedangkan karakteristik usia responden rata-rata usia lansia sebanyak 13 orang atau sebesar 86,7\%. Menurut Surwanto (2009), prevalensi hipertensi meningkat seiring dengan bertambahnya usia. Hal ini mendukung penelitian saat ini karena dari 15 responden, sebanyak 13 yang orang termasuk usia lansia.

Distribusi berdasarkan tekanan darah sistol pre-test dapat diketahui bahwa dari 15 responden, didapatkan nilai mean atau rata-rata tekanan darah sistol sebesar 162 $\mathrm{mmHg}$, dan nilai standar deviasi sebesar 15,213. Sedangkan distribusi berdasarkan tekanan darah diastol pre-test dapat diketahui bahwa dari 15 responden, didapatkan nilai median sebesar 90 $\mathrm{mmHg}$, nilai minimum sebesar $80 \mathrm{mmHg}$, dan nilai maximum sebesar 100 .

Menurut Huda Amin dan Hardi (2015), hipertensi adalah terjadi peningkatan tekanan darah sistolik sedikitnya $140 \mathrm{mmHg}$ dan tekanan diastolik sedikitnya $90 \mathrm{mmHg}$. penderita Hipertensi selain berisiko tinggi menderita penyakit jantung, juga berisiko menderita penyakit lain seperti penyakit saraf, ginjal, dan pembuluh darah dan semakin tinggi tekanan darah, makin besar resikonya. Untuk itu perlu dilakukan penanganan, baik secara farmakologis maupun secara nonfarmakologis. Akhir- akhir ini 
pengobatan yang sering dilakukan oleh masyarakat adalah mengonsumsi tanaman herbal yang mampu menurunkan tekanan darah.

Daun sirsak akhir-akhir ini sering digunakan sebagai pengobatan alternatif hipertensi. Kandungan daun sirsak yang diperkirakan dapat menurunkan tekanan darah adalah kalium. Ion kalium dalam cairan ekstrasel akan menyebabkan jantung relaksasi dan juga membuat frekuensi denyut jantung menjadi lambat. Selain itu kalium juga bisa mengatur keseimbangan cairan tubuh bersama natrium, menghambat pengeluaran renin, berperan dalam vasodilatasi arteriole, dan mengurangi respon vasokonstriksi endogen, sehingga tekanan darah menurun (Joe, 2012).

Distribusi berdasarkan tekanan darah sistol post-test dapat diketahui bahwa dari 15 responden, didapatkan nilai mean sebesar $146 \mathrm{mmHg}$, dan nilai standar deviasi sebesar 19,567. Sedangkan berdasarkan tekanan darah diastol post-test dapat diketahui bahwa dari 15 responden, didapatkan nilai median yaitu sebesar 80 $\mathrm{mmHg}$, nilai minimum sebesar $80 \mathrm{mmHg}$, dan nilai maximum sebesar $100 \mathrm{mmHg}$

Hipertensi adalah terjadi peningkatan tekanan darah sistolik sedikitnya $140 \mathrm{mmHg}$ dan tekanan diastolik sedikitnya $90 \mathrm{mmHg}$. penderita Hipertensi selain berisiko tinggi menderita penyakit jantung, juga berisiko menderita penyakit lain seperti penyakit saraf, ginjal, dan pembuluh darah dan semakin tinggi tekanan darah, makin besar resikonya (Huda Amin \& Hardi, 2015).

Hipertensi atau tekanan darah tinggi adalah suatu peningkatan abdormal tekanan darah dalam pembuluh darah arteri secara terus menerus lebih dari suatu periode. Hal ini terjadi bila arteriolearteriole berkonstriksi. Konstriksi arteriole membuat darah sulit mengalir dan meningkatkan tekanan melawan dinding arteri. Hipertensi menambah beban kerja jantung dan arteri yang bila berlanjut dapat menimbulkan kerusakan jantung dan pembuluh darah.

Pengobatan yang sering dilakukan oleh penderita hipertensi adalah mengonsumsi tanaman herbal yang mampu menurunkan tekanan darah. Daun sirsak akhir-akhir ini sering digunakan sebagai pengobatan alternatif hipertensi. Secara teoritis daun sirsak memiliki antioksidan yang dapat menangkal radikal bebas, sama halnya bahan alami lainnya, antioksidan ini dapat melenturkan dan melebarkan pembuluh darah serta menurunkan tekanan darah.

Hasil penelitian ini sejalan dengan penelitian yang dilakukan oleh Huber Hansel (2015). Pengaruh Teh Daun Sirsak Terhadap Penurunan Tekanan Darah Normal Pada Laki-Laki Dewasa Muda. 
Menggunakan metode prospektif eksperimantal laboratorium quasi. Dengan desain penelitian pre-test dan post-test, dengan menggunakan uji " $\mathrm{t}$ " berpasangan dan uji "t" tidak berpasangan. Hasil uji " $T$ " berpasangan $(p=0,000)$ menunjukkan penurunan tekanan darah yang sangat bermakna.

Hasil penelitian menunjukkan bahwa hasil normalitas tekanan darah sistol pretest didapatkan nilai Tests of Normality shapiro-wilk yaitu 0,099 atau >0,05, dan tekanan darah sistol post-tes di dapatkan nilai 0,065. Tests of Normality shapirowilk untuk tekanan darah diastol pre-test didapatkan nilai 0,001 atau $<0,05$ dan nilai tekanan darah diastol post-test adalah 0,000. Sehingga syarat untuk uji $T$ berpasangan tidak terpenuhi, karena data tekanan darah diastol tidak normal. Oleh karena itu digunakan uji alternative Wilcoxon.

Dari hasil uji Wilcoxon tekanan darah sistol didapatkan nilai $p<\alpha$ $(p=<0.001)$, dan tekanan darah diastol didapatkan nilai $(p=0.002)$, maka dapat disimpulkan bahwa, "Ada efektivitas daun sirsak terhadap penurunan tekanan darah di wilayah kerja Puskesmas Balibo Kecamatan Kindang Kabupaten Bulukumba." Artinya terjadi penurunan tekanan darah pada penderita hipertensi setelah diberikan daun sirsak.
Penelitian ini sejalan penelitian Hubert Hansel (2015).Pengaruh Teh Daun Sirsak Terhadap Penurunan Tekanan Darah Normal Pada Laki-Laki Dewasa Muda. Menggunakan uji " $t$ ” berpasangan dan uji " $t$ " tidak berpasangan. Hasil uji " $T$ " berpasangan $(p=0,000)$ menunjukkan penurunan tekanan darah yang sangat bermakna, sedangkan untuk uji " $T$ " tidak berpasangan menunjukkan terdapat perbedaan presentase penurunan yang tidak bermakna nilai $(\mathrm{p}=0,417>0,05)$.

Menurut Huda Amin dan Hardi (2015) hipertensi adalah terjadi peningkatan tekanan darah sistolik sedikitnya $140 \mathrm{mmHg}$ dan tekanan diastolik sedikitnya $90 \mathrm{mmHg}$. penderita Hipertensi selain berisiko tinggi menderita penyakit jantung, juga berisiko menderita penyakit lain seperti penyakit saraf, ginjal, dan pembuluh darah dan semakin tinggi tekanan darah, makin besar resikonya. Apabila individu mengalami hipertensi dan tidak mendapatkan pengobatan dan pengendalian secara teratur (rutin), maka penderita bisa mengalami kasus-kasus serius bahkan kematian. Salah satu pengobatan hipertensi adalah dengan mengonsumsi tanaman herbal seperti daun sirsak, yang dikenal ampuh menurunkan tekanan darah.

Secara teoritis daun sirsak memiliki antioksidan yang dapat menangkal radikal bebas, sama halnya bahan alami lainnya, 
antioksidan ini dapat melenturkan dan melebarkan pembuluh darah serta menurunkan tekanan darah. Selain antioksidan, kandungan daun sirsak yang diperkirakan dapat menurunkan tekanan darah adalah kalium. Ion kalium dalam cairan ekstrasel akan menyebabkan jantung relaksasi dan juga membuat frekuensi denyut jantung menjadi lambat. Selain itu kalium juga bisa mengatur keseimbangan cairan tubuh bersama natrium, menghambat pengeluaran renin, berperan dalam vasodilatasi arteriole, dan mengurangi respon vasokonstriksi endogen, sehingga tekanan darah menurun (Joe, 2012).

Selain mengobati hipertensi, secara tradisional daun sirsak biasa digunakan untuk mencegah berbagai macam penyakit seperti menurunkan nyeri pada penderita gout artritis, hal ini dibuktikan oleh penelitian Karundeng F. Gerry (2015) "Pengaruh Mengkonsumsi Rebusan Daun Sirsak Terhadap Penurunan Nyeri Pada Penderita Gout Artritis Wilayah Kerja Puskesmas Pineleng." Tujuan penelitian ini untuk menganalisis pengaruh mengkonsumsi rebusan daun sirsak terhadap penurunan nyeri pada penderita gout artritis di wilayah kerja Puskesmas Pineleng. Menggunakan desain penelitian time series desaign dan data yang dikumpulkan dari responden menggunakan lembar observasi. Hasil penelitian uji wilcoxon sign rank test pada hasil akhir didapatkan nila $\mathrm{p}=0,004$, sehingga dapat diambil kesimpulan bahwa hipotesis diterima atau ada pengaruh rebusan daun sirsak terhadap penurunan nyeri pada penderita gout artritis di wilayah kerja puskesmas pineleng.

Analisa peneliti terkait penelitian ini adalah daun sirsak memiliki kandungan yang dapat mengobati berbagai macam penyakit khususnya hipertensi. Kandungan daun sirsak seperti antioksidan dan ion kalium dapat menurunkan tekanan darah namun, berbeda penurunan antara tekanan darah sistol dan diastol, beberapa subjek penelitian tidak terjadi penurunan tekanan darah diastol, kemudian penurunan tekanan darah setiap individu juga berbeda, peneliti berpendapat hal ini disebabkan karena setiap proses metabolisme individu berbeda, pemberian daun sirsak kurang efektif karena hanya satu kali dan faktor lain adalah makanan yang sebelumya di konsumsi oleh responden.

\section{KESIMPULAN DAN SARAN}

Dapat disimpulkan bahwa, Ada efektivitas daun sirsak terhadap penurunan tekanan darah pada penderita hipertensi di wilayah kerja Puskesmas Balibo Kecamatan Kindang Kabupaten Bulukumba dengan nilai tekanan darah sistol didapatkan nilai $p<\alpha(p=<0.001)$, 
dan tekanan darah diastol didapatkan nilai $p<\alpha(p=0.002)$.

Berdasarkan manfaat yang telah dikemukakan pada bab sebelumnya, maka saran yang dapat diberikan oleh peneliti adalah, Diharapkan penelitian ini menjadi sumber informasi atau bahan referensi bagi peneliti selanjutnya, Diharapkan bagi penderita hipertensi dan tenaga kesehatan untuk memanfaatkan daun sirsak sebagai pengobatan penyakit hipertensi, Bagi penelitian keperawatan diharapkan dapat dilakukan penelitian lanjutan mengenai efektivitas daun sirsak terhadap penderita hipertensi dengan desain penelitian, jumlah sampel dan karakteristik responden yang berbeda.

\section{DAFTAR PUSTAKA}

Abbas Sarah Isam. (2015). Identification

Of Some Annona Muricata L.

(Soursop).

<https://www.researchgate.net/profile/

Mustafa_Mohammed7/publication/29

3568551_Identification_of_Some_An

nona_Muricata_LSoursop_Component

s_and_Their_Antioxidant_Effects_in_

Rats/links/56b98d0b08ae9d9ac67dd57

c.pdf?origin=publication list $>$.

Achmadi Umar Fahmi. (2013). Kesehatan

Masyarakat Teori Dan Aplikasi.

Rajawali Pers: Jakarta.
Akmal Mutaroh, et, al., (2016).

Ensiklopedi Kesehatan. Ar-Ruzz Media: Jakarta.

Daley Debra. (2015). 30 Menit

untuk Bugar dan Sehat. PT Bhuana

Ilmu Populer. Jakarta.

Dr. Kurniadi Helmanu \& Nurrahmi Ulfa. (2015). Stop Diabetes Hipertensi

Kolestrol Tinggi Jantung Koroner.

Istana Media:Yogyakarta.

Haro Gindo (2014). Study Of The

Antibacterial Activities Of Soursop

(Annona Muricata L) Leaves

$<$ https://www.slideshare.net/astrijongl

$\underline{\text { u/study-of-the-antibacterial-activities- }}$

of-soursop-annona-muricata-l-leave>.

Hidayat Alimul Aziz A. (2011). Metode

Penelitian Kebidanan \& Teknik

Analisa Data. Salemba

Medika:Jakarta.

Http://article.sciencepublishinggroup.c om/pdf/10.11648.j.bio.20150305.12.p

df.

Http://www.ijastnet.com/journals/Vol

2 No 1 January 2012/19.pdf.

Http://www.jcdr.net/articles/PDF/8762 /18329 CE\%28EK\%29 F\%28AK\%2 9 PF1\%28NEAK\%29 PFA\%28AK\%

29_PF2\%28EKAK\%29.pdf.

Huda Amin Nurarif \& Kusuma Hardi.

(2015). Aplikasi Asuhan

Keperawatan Berdasarkan

Diagnosa Medis \& NANDA NIC-

NOC. Media Action: Jogjakarta. 
Joe Wulan. (2012). Dahsyatnya Khasiat Sirsak Untuk Banyak Penyakit Yang Mematikan. Andi Offset: Yogyakarta. Junaedi Edi, et, al., (2013). Hipertensi Kandas Berkat Herbal. F.Media: Jakarta.

Dharma Kusuma Kelana. (2011).

Metodologi Penelitian

Keperawatan (Pedoman

Melaksanakan dan Menerapkan

Hasil Penelitian). Trans Info

Media: Jakarta.

Nuraini Dini Nuris. (2014). Aneka Daun

Berkhasiat Untuk Obat. Gava

Media: Yogyakarta.

Nur Rachmani Eka Prasasti (2012). The

Breast Of Anticancer From Leaf

Extract Of Annona Muricata

Againts Cell Line In T47D.

http://www.ijastnet.com/journals/Vol

2_No_1_January_2012/19.pdf

Pai BH Mithun. (2016). Anti-Microbial

Efficacy Of Soursop Leaf Soursop

(Annona Muricata) On Oral

Pathogens: An In-Vitro Study.

<https://www.google.com/webhp?ie=

utf-

$\underline{8 \& o e=u t f 8 \# q=j o u r n a l+a n t i m i c r o b i a l+}$

efficacy+of+soursop+leaf+soursop $+\%$

28annona+muricata\%29+on+oral+pat

hogens:+an+in+vitro+study+pdf+oleh

+ BH+mithun+pai\&*>.
Rahmawati. (2013). Hubungan Merokok

Dengan Kejadian Hipertensi Di

Puskesmas Borong Rappoa

Kecamatan Kindang Kabupaten

Bulukumba.Hal 2.

Silpawati. (2012). Hubungan Tingkat

Kecemasan dengan Peningkatan

Tekanan Darah. Hal 8.

Soeryoko Hery. (2010). 20 Tanaman Obat

Terpopuler Penurun Hipertensi.

Andi Offset: Yogyakarta.

Sujarweni Wiratna. V. (2014). Metodologi

Penelitian Keperawatan. Gava

Media. Yogyakarta.

Stikes Panrita Husada. (2017). Buku

Panduan Penyusunan Skripsi.

Ooasa: Bulukumba.

Syamsuddin, et, al., (2015). Pedoman

Praktis Metodologi Penelitian.

Wade Group: Ponorogo Indonesia.

Udjianti Juni Wajan. (2013). Keperawatan

Kardiovaskular. Salemba Medika:

Jakarta. 
Tabel 1 Distribusi Jumlah Responden Berdasarkan Karakteristik Penderita Hipertensi, Tekanan Darah Sistol Pretest dan Tekanan Darah Diastol Pretest di Wilayah Kerja Puskesmas Balibo Kecamatan Kindang Kabupaten Bulukumba

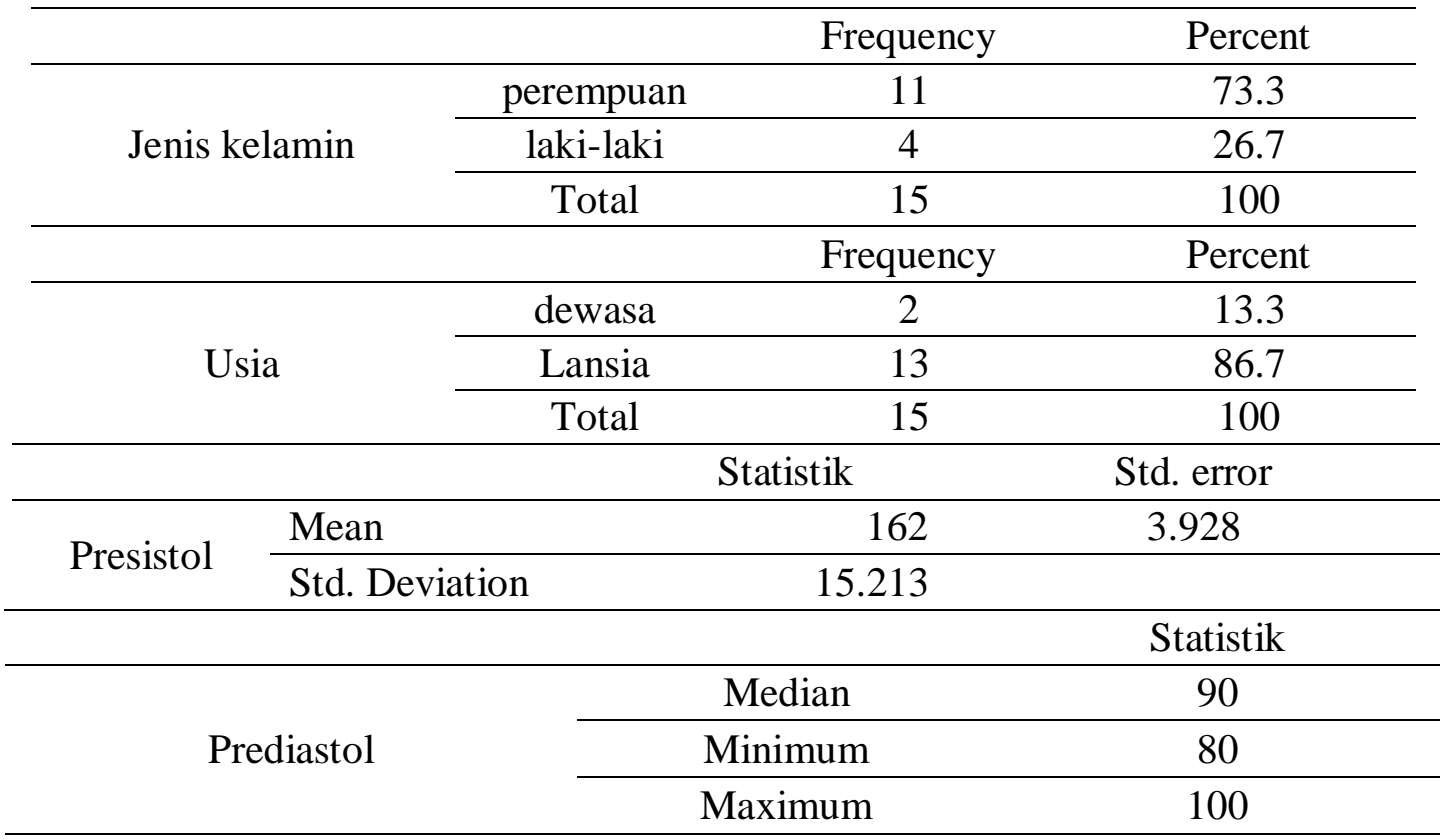

Tabel 2 Distribusi Jumlah Responden Berdasarkan Tekanan Darah Diastol Post-test pada Penderita Hipertensi di Wilayah Kerja Puskesmas Balibo Kecamatan Kindang

\begin{tabular}{llcc}
\hline & & \multicolumn{2}{c}{ Statistik } \\
\hline \multirow{3}{*}{ Postdiastol } & Median & 80 & \\
\cline { 2 - 4 } & Minimum & 80 & 100 \\
\cline { 2 - 4 } & Maximum & 100 \\
\hline
\end{tabular}

Tabel 3 Menilai Efektivitas Daun Sirsak terhadap Penurunan Tekanan Darah Sistol dan Diastol pada Penderita Hipertensi di Wilayah Kerja Puskesmas Balibo Kecamatan Kindang

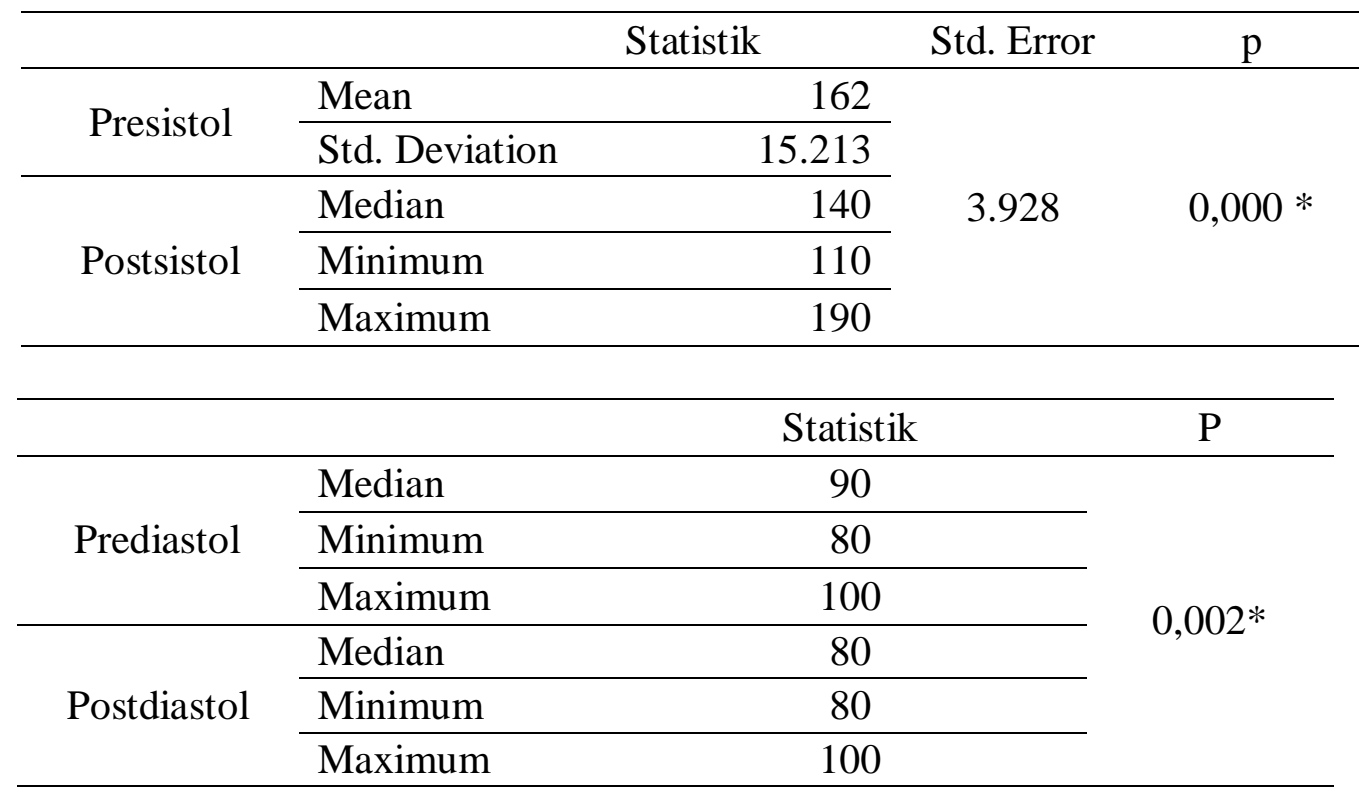

